Јелена Д. Пухар ${ }^{*}$

Универзитет у Београду

Филолошки факултет https://doi.org/10.18485/analiff.2020.32.1.16

811.131.1’367

Originalni naučni rad

Primljen: 12.03.2020.

Prihvaćen: 14.06.2020.

\title{
ДЕЛИМИЧНА СУБЈЕКАТСКА КОНТРОЛА ИНФИНИТИВНИХ ДОПУНСКИХ КОНСТРУКЦИЈА СА ФИНАЛНОМ ВРЕДНОШЋУ У ИТАЛИЈАНСКОМ ЈЕЗИКУ
}

\begin{abstract}
У овоме раду смо се, у теоријском оквиру генеративне граматике, бавили остварењем делимичне субјекатске контроле у инфинитивним допунским конструкцијама са финалном вредношћу у италијанском језику. Анализу смо спровели на примерима преузетим из корпуса Корис (Coris), као и на примерима забележеним у писаном језику италијанских електронских и штампаних медија. Наше испитивање је потврдило претпоставку М. Шијан (Sheehan, 2014) да конструкције делимичне субјекатске контроле у италијанском језику садрже реципрочне глаголе, из чега следи да је имплицитни субјекат инфинитивних конструкција (PRO) увек семантички у множини. На примеру забележеном у корпусу, следећи теорију померања (Rodrigues, 2007; Boeckh, Hornstein et al., 2010; Kapetangianni, 2010), приказали смо деривацију инфинитивне допунске конструкције са финалном вредношћу делимичне субјекатске контроле, чиме смо показали да субјекат управне реченице не контролише у потпуности имплицитни субјекат инфинитивне конструкције делимичне контроле.
\end{abstract}

Кључне речи: делимична контрола, имплицитни субјекат, инфинитивне допунске конструкције са финалном вредношћу, италијански језик, генеративна граматика

\section{Увод}

У генеративној лингвистици конструкције делимичне субјекатске контроле (partial subject control) подразумевају конструкције у којима субјекат управних реченица није једини контролор имплицитног субјекта зависних реченица (Landau, 2000: 26; Pitteroff, Alexiadou et al., 2017: 201). Дакле, субјекат управних реченица у таквим кон-

jelenapuhar@yahoo.com 
струкцијама делимично контролише фонетски неисказани субјекат зависних реченица.

Конструкције делимичне контроле су се испрва проучавале у енглеском језику (Wilkinson, 1971; Lawler, 1972; Williams, 1980). Kacније су, захваљујући Ландаувој студији (Landau, 1999), постале предмет истраживања у португалском (Rodrigues, 2007; Sheehan, 2012, 2018), пољском (Witkos \& Snarska, 2008), шпанском (Sheehan, 2014), француском (Sheehan, 2014; Authier \& Reed, 2018) и немачком језику (Pitteroff, Alexiadou et al., 2017).

Конструкције делимичне контроле у италијанском језику у својим радовима помињу Ландау (Landau, 2000), Родригес (Rodrigues, 2007), Шијан (Sheehan, 2012), Ђандозо (Giandoso, 2014), али их подробније не анализирају, те је циљ овога рада да се, у оквиру теорије контроле померања (Movement Theory of Control) ${ }^{1}$, испита успостављање делимичне субјекатске контроле у инфинитивним конструкцијама у савременом италијанском језику. У овоме раду полазимо од претпоставке да инфинитивне конструкције делимичне контроле садрже реципрочне глаголе (Kapetangianni, 2010; Sheehan, 2014) и да је контролисани елемент синтаксички вишечлан елемент (Rodrigues, 2007; Kapetangianni, 2010). У центру пажње нашега испитивања биће анализа семантичке вредности имплицитног субјекта зависних реченица.

Истраживање смо ограничили на инфинитивне допунске конструкције са финалном значењском компонентом уведене глаголима. Финално значење таквих конструкција проистиче из значења управних глагола, који исказују жељу, настојање, труд, тежњу, намеру, кретање (Moretti \& Orvieto, 1980: 74, 77; Prandi, 1995: 62, 65; Prandi, Gross et al., 2005: 145; Biagini, 2013: 93). Ради илустрације навешћемо неколико примера ${ }^{2}$ :

(1) Vado a comprare il pane. 'Идем да купим хлеб.'

(2) Sono corso a comprare il pane. 'Отрчао сам да купим хлеб.'

1 Према теорији контроле померања, PRO је траг А-померања (в. Boeckh, Hornstein et al. 2010).

2 Примери (1)-(3) преузети су из Prandi (1995: 62, 65). Пример (4) преузет је из Skytte (1983: 155). 
(3) Giorgio tende a non trascurare gli amici. ‘Ђорђо тежи да не запостави пријатеље.'

(4) Tu ti sforzi di nasconderlo. 'Ти се трудиш да то сакријеш.'

У примерима (1) и (2) инфинитивне конструкције су допуна глагола кретања, чија се радња предузима ради остварења постављеног циља исказаног зависним реченицама. У (3) зависна реченица је допуна глагола који изражава тежњу ка остварењу циљне радње, а у (4) инфинитивна конструкција допуњује глагол који исказује улагање труда ради реализације садржаја зависне конструкције.

Један део примера којима ћемо приказати остварење делимичне контроле у инфинитивним допунским конструкцијама са финалном вредношћу у италијанском језику преузет је из Кориса (Coris) ${ }^{3}$, корпуса писаног италијанског језика. Овај корпус, израђен на Универзитету у Болоњи, садржи сто двадесет милиона речи и ажурира се на сваке три године. Поред примера из корпуса, навешћемо и примере које смо преузели из писаног језика италијанских штампаних и електронских медија.

\section{Инфинитивне допунске конструкције са финалном вредношћу делимичне субјекатске контроле}

У следећим примерима, забележеним у нашој грађи, контролне структуре се састоје из управних реченица са глаголима чије је значење намере $(5,6)$ и настојања $(7)$ усмерено ка остварењу циља и из инфинитивних допунских конструкција којима је тај циљ исказан:

(5)

\begin{tabular}{|c|c|c|c|c|}
\hline Io & penso & di & PRO & allearmi. (Il Mattino 6.9.2019) \\
\hline Ja-1SG & намеравати-PRES.1SG & COMP & & удружити-PRES.INF \\
\hline ce- REF & $1 \mathrm{SG}$ & & & \\
\hline
\end{tabular}

$\begin{array}{llll}\text { (6) } & \text { pensi } & \text { di } & \text { PRO riconciliarti? (Il Venerdì 2.8.2019) } \\ \text { Ти-2SG } & \text { намеравати-PRES.2SG } & \text { COMP } & \text { помирити-PRES.INF }\end{array}$ ce- REFL.2SG

'Ти намераваш да се помириш?'

3 http://corpora.dslo.unibo.it/TCORIS/ 
Јелена Д. Пухар

$\begin{array}{llll}\text { Paola } & \text { cerca } & \text { PRO } & \text { rappacificarsi. (Il Giorno 5.8.2019) } \\ \text { Паола-3SG } & \text { настојати-PRES.3SG COMP } & \text { помирити-PRES.INF } \\ \text { се-REFL.3SG } & \\ \text { 'Паола настоји да се помири.' } & \end{array}$

Дати примери показују да субјекат управних реченица, одн. делимични контролор инфинитивних допунских конструкција са финалном вредношћу, и повратне клитике узајамно-повратних глагола у инфинитивним конструкцијама имају иста морфолошка обележја, што потврђује претпоставку М. Шијан (2012) да контролисани елемент конструкција делимичне контроле у романским језицима може делити своја морфолошка обележја са контролором ${ }^{4}$. Наведени примери указују да се на анализиране конструкције делимичне контроле са узајамно-повратним глаголима односи следећа тврдња: а) уколико је делимични контролор у првом лицу једнине, у првом лицу једнине је и повратна клитика, б) ако је делимични контролор у другом лицу једнине, и повратна клитика стоји у другом лицу једнине, в) када је делимични контролор у трећем лицу једнине, у истом лицу је и повратна клитика.

На основу подударности морфолошких обележја делимичног контролора и повратних клитика у инфинитивним конструкцијама, могло би се закључити да је имплицитни субјекат инфинитивних конструкција семантички у једнини. Међутим, све наведене инфинитивне конструкције садрже узајамно-повратне глаголе, који подразумевају радњу коју један на другом врше најмање два учесника. Из тога следи да, семантички, субјекат управних реченица не може бити једини контролор конструкција делимичне субјекатске контроле (Barrie \& Pittman, 2004: 75), те је имплицитни субјекат зависних конструкција вишечлан елемент, који се састоји од делимичног контролора, субјекта управне реченице, и фонетски неисказане заменице pro $^{5}$ (Rodrigues, 2007: 220).

4 Контролне структуре попут примера Ha suggerito di incontrarci in un ristorante giapponese. (Coris: MON2014_16) 'Предложио је да се сретнемо у једном јапанском ресторану', у којима се не подударају морфолошка обележја повратних клитика узајамно-повратних глагола зависних реченица и делимичног контролора, превазилазе оквире овога рада, те их остављамо за даља истраживања.

5 Празну категорију pro у овоме раду користимо како бисмо означили фонетски неисказану заменицу у саставу вишечланог имплицитног субјекта 
Да бисмо установили семантичку вредност имплицитног субјекта инфинитивних конструкција у примерима забележеним у грађи, фонетски исказаним контролорима додаћемо фонетски неисказане заменице, чија је вредност условљена одговарајућим контекстом:

(8) Io penso di PRO allearmi. (Il Mattino 6.9.2019)

'Ја намеравам да се удружим.'

$\mathrm{PRO}=$ io + tu / lui / lei / Lei / voi / loro (PRO = ‘ ja + ти / он / она / Ви / ви / они / оне')

Io penso di PRO1PL allearmi.

(9) Tu pensi di PRO riconciliarti? (Il Venerdì 2.8.2019)

'Ти намераваш да се помириш?'

a) $\mathrm{PRO}=$ tu + io $/$ noi $\left(\mathrm{PRO}=\right.$ ' $^{\text {ти }}+$ ja $/$ ми' $)$

Tu pensi di PRO1PL di riconciliarti?

б) $\mathrm{PRO}=\mathrm{tu}+$ lui $/$ lei $/$ loro $(\mathrm{PRO}=$ ' 'ти + он / она / они / оне' $)$

Tu pensi di PRO2PL riconciliarti?

(10) Paola cerca di PRO rappacificarsi. (Il Giorno 5.8.2019)

'Паола настоји да се помири.'

a) $\mathrm{PRO}=$ Paola + io $/$ noi $(\mathrm{PRO}=$ ' Паола + ja / ми')

Paola cerca di PRO1PL rappacificarsi.

б) $\mathrm{PRO}=$ Paola + tu $/$ Lei / voi $(\mathrm{PRO}$ = 'Паола + ти / Ви / ви')

Paola cerca di PRO2PL rappacificarsi.

в) PRO = Paola + lui / lei / loro (PRO = 'Паола + он / она / они / оне')

Paola cerca di PRO3PL rappacificarsi.

У примеру (8) контролисани елемент је морфолошки у првом лицу једнине. Међутим, семантички, он подразумева и фонетски неисказану заменицу, која може бити у другом или трећем лицу једнине

инфинитивних конструкција делимичне контроле (в. Rodrigues, 2007: 220) 
или множине. Будући да је делимични контролор инфинитивне конструкције у првом лицу једнине, без обзира на лице фонетски неисказане заменице, контролисани елемент је семантички у првом лицу множине и односи се на групу којој припада говорник и која може укључивати саговорника или лице о којем се говори. У примеру (9) имплицитни субјекат је, као и његов делимични контролор, морфолошки у другом лицу једнине, али он семантички може бити у првом лицу множине (уколико укључује заменицу у првом лицу једнине или множине) или у другом лицу множине (када подразумева заменицу у трећем лицу једнине или множине). Пример (10) показује да у конструкцијама са делимичним контролором у трећем лицу једнине PRO семантички може бити у првом лицу множине (ако фонетски неисказана заменица има вредност првог лица једнине или множине), у другом лицу множине (када подразумева заменицу у другом лицу једнине или множине или хонорифичку заменичку форму у трећем лицу једнине) или у трећем лицу множине (уколико је фонетски неисказана заменица у трећем лицу једнине или множине).

Поред инфинитивних конструкција са контролором у морфолошкој једнини, у нашој грађи смо издвојили и структуре са контролором у морфолошкој множини. Те конструкције је могуће двојако анализирати. С једне стране, могу се тумачити као конструкције потпуне контроле, уколико се контролисани елемент морфолошки и семантички сматра истоветним контролору. Навешћемо неколико примера који то потврђују:

[Noi]i avevamo progettato di PROi incontrarci

[Ми] планирати-TR.PROSS.1PL COMP срести-PRES.INF ce-REFL.1PL

in caffetteria [...] (Coris: MON2014_16)

у кафетерији [...]

'[Ми] планирали смо да се сретнемо у кафетерији.'

[Noi] avevamo progettato di PRO1PL incontrarci in caffetteria. 
a) $\mathrm{PRO}=\mathrm{voi}+$ io $/$ noi $(\mathrm{PRO}=$ 'ви + ja / ми' $)$

[Voi] vi impegnate a PRO1PL vedervi ogni fine settimana.

б) $\mathrm{PRO}=$ voi + lui / lei / loro (PRO = 'ви + он / она / они / оне')

[Voi] vi impegnate a PRO2PL a vedervi ogni fine settimana.

(16) Alcuni automobilisti si fermano a PRO salutarsi. (Coris: STAMPA Quotidiani) 'Неки возачи се заустављају како би се поздравили.'

a) $\mathrm{PRO}=$ alcuni automobilisti + io / noi $(\mathrm{PRO}=$ 'неки возачи + ja / ми')

Alcuni automobilisti si fermano a PRO1PL salutarsi.

б) $\mathrm{PRO}=$ alcuni automobilisti + tu / Lei / voi (PRO = 'неки возачи + ти / Ви / ви') Alcuni automobilisti si fermano a PRO2PL salutarsi.

в) $\mathrm{PRO}=$ alcuni automobilisti + lui $/$ lei / loro $(\mathrm{PRO}=$ 'неки возачи + он / она / они / оне')

Alcuni automobilisti si fermano a PRO3PL salutarsi.

У (14) морфолошка обележја повратне клитике показују да је имплицитни субјекат, као и његов делимични контролор, морфолошки у првом лицу множине. Уколико се ова контролна структура тумачи као структура делимичне контроле, контролисани субјекат је семантички такође у првом лицу множине, али се сматра вишечланим елементом који укључује делимични контролор и фонетски неисказану заменицу. Исто тако, имплицитни субјекти инфинитивних конструкција у примерима (15) и (16), поред контролора, могу укључивати и фонетски неисказане заменице. У зависности од вредности фонетски неисказане заменице, PRO у (15) семантички може бити у првом или другом лицу множине, а у (16) у првом, другом или трећем лицу множине. На основу датих примера се закључује да су морфолошка обележја повратних клитика реципрочних глагола у инфинитивним конструкцијама и у контролним структурама са контролором у морфолошкој множини истоветна морфолошким обележјима делимичног контролора. 
Делимична се контрола у допунским инфинитивним конструкцијама са финалном значењском компонентом у италијанском језику може остварити и немаркираним лексички реципрочним глаголима ${ }^{6}$. Ево примера који то приказују:

$$
\begin{aligned}
& \begin{array}{l}
\text { Cercherò } \\
\text { настојати-FUT.1SG COMP }
\end{array} \\
& \text { 'Настојаћу да сарађујем.' } \\
& \text { PRO }=\text { io + tu / lui / lei / Lei / voi / loro } \\
& \text { (PRO = ‘ja + ти / он / она / Ви / ви / они / оне') }
\end{aligned}
$$$$
\text { сарађивати-PRES.INF }
$$

Cercherò di PRO1PL collaborare.

(18)

$\begin{array}{llll}\text { Vuoi } & \text { sempre } & \text { PRO } & \begin{array}{l}\text { litigare. (Coris: MON2014_16) } \\ \text { желети-PRES.2SG }\end{array} \\ \text { увек } & & \text { свађати ce-PRES.INF }\end{array}$

'Желиш увек да се свађаш.'

a) $\mathrm{PRO}=\mathrm{tu}+$ io $/$ noi $(\mathrm{PRO}=$ 'ти + ja $/$ ми' $)$

Vuoi sempre PRO1PL sempre litigare.

б) $\mathrm{PRO}=$ tu + lui $/$ lei / loro (PRO = 'ти + он / она / они / оне')

Vuoi sempre PRO2PL sempre litigare.

$\begin{array}{llll}\text { Alfio e Paolo } \quad \text { restarono } & \text { a } & \text { PRO } \\ \text { Алфио и Паоло } & \text { остати-PASS.REM.3PL } & \text { COMP } & \\ \text { chiacchierare. (Coris: MON2001_04) } & & \\ \text { ћаскати-PRES.INF } & \end{array}$

‘Алфио и Паоло су остали да ћаскају.'

a) $\mathrm{PRO}=$ Alfio e Paolo + io $/$ noi $($ PRO = 'Алфио и Паоло + ja $/$ ми' $)$

Alfio e Paolo restarono a PRO1PL chiacchierare.

6 Немаркирани лексички реципрочни глаголи се дефинишу као глаголи код којих је глаголска лексема носилац реципрочног значења. Реципрочно значење није морфолошки обележено повратним клитикама (Miličević, 2004: 32). 
б) $\mathrm{PRO}=$ Alfio e Paolo + tu / Lei / voi $(\mathrm{PRO}=$ 'Алфио и Паоло + ти / Ви / ви’ $)$

Alfio e Paolo restarono a PRO2PL chiacchierare.

в) $\mathrm{PRO}=$ Alfio e Paolo + lui / lei / loro $(\mathrm{PRO}=$ 'Алфио и Паоло + он / она / они / оне')

Alfio e Paolo restarono a PRO3PL chiacchierare.

Немаркирани лексички реципрочни глаголи, као и узајамноповратни глаголи захтевају присуство двају учесника у ситуацији, па се у забележеним примерима имплицитни субјекат инфинитивних конструкција може тумачити као вишечлан синтаксички субјекат, који, у зависности од контекста, има различиту семантичку вредност. Уколико је делимични контролор у првом лицу, PRO је семантички у првом лицу множине (17). У примеру (18) са контролором у другом лицу, имплицитни субјекат је у првом лицу множине (када је имплицитна заменица у првом лицу једнине или множине) или другом лицу множине (уколико имплицитна заменица има вредност трећег лица једнине или множине). Контролисани елемент са контролором у трећем лицу, као у (19), може бити у првом лицу множине (ако је фонетски неисказана заменица у првом лицу једнине или множине), другом лицу множине (у конструкцијама са фонетски неисказаном заменицом у другом лицу једнине или множине или са нултом хонорифичком заменичком формом) или у трећем лицу множине (ако је фонетски неисказана заменица у трећем лицу једнине или множине).

\section{Деривација инфинитивних конструкција са финалном значењском компонентом делимичне субјекатске контроле}

На примеру Sofia cerca di lottare 'Софија настоји да се бори', у оквиру теорије померања, посредством операција спајања (merge) и померања (move), приказаћемо деривацију допунске инфинитивне конструкције делимичне субјекатске контроле. Структуру забележе- 
ног примера представићемо синтаксичким стаблима, која омогућују хијерархијски приказ реченица помоћу фраза VP, TP, $\mathrm{CP}^{8}$.

Контролна структура Sofia cerca di lottare састоји се из управне реченице Sofia cerca и зависне реченице di lottare. Зависна реченица садржи лексички реципрочан глагол, па је, семантички, имплицитни субјекат вишечлан елемент. Следећи анализу контролних структура насталих померањем (Rodrigues, 2007; Kapetangianni, 2010), синтаксичком операцијом спајања конституента Sofia и фонетски нереализоване личне заменице pro настаје детерминативна фраза Sofia pro, која је семантички у множини. Та фраза се синтаксичком операцијом спајања сједињује са глаголом lottare ('борити се’). Реченична структура се у овој тачки деривације може приказати следећим синтаксичким стаблом:

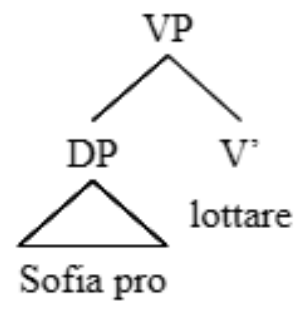

Као што се може видети из приказаног стабла, детерминативна фраза Sofia pro је екстерни аргумент глагола lottare. Налази се у спецификатору глаголске фразе, где проверава семантичку улогу глагола и прима улогу агенса. Глагол lottare је лексички реципрочни глагол, захтева семантички субјекат у множини, па се семантичка улога агенса додељује целој детерминативној фрази.

У следећој тачки деривације операцијом спајања Т и VP, настаје T', након чега се конституент Sofia копира. Његова копија заузима позицију спецификатора временске фразе, где би требало да провери обележје принципа проширене пројекције категорије Т ${ }^{9}$. Међутим,

8 Глаголска фраза (VP) садржи глагол и глаголске аргументе, временска фраза (ТР) односи се на глаголске категорије времена, начина, вида, лица, комплементизаторска фраза (СР) тиче се међурелација између синтаксе и прагматике (в. Puglielli \& Frascarelli, 2008).

9 Према принципу проширене пројекције (Extended Projection Principle) 
будући да Т нема обележја флексије јер је инфинитив lottare нефинитни облик и не помера се са своје почетне позиције, падеж конституента Sofia у овој тачки деривације не може се проверити. У следећој тачки, деривацији приступа комплементизатор $d i$ и спаја се са T, као што је приказано синтаксичким стаблом:

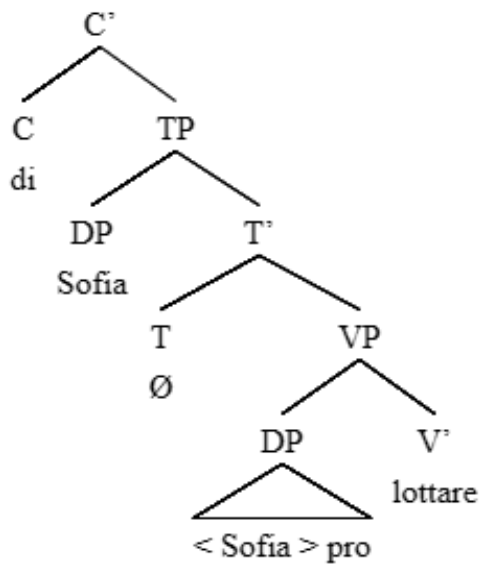

Када деривацији приступи глагол cerca, позиција екстерног аргумента глагола је празна, па се конституент Sofia поново копира и помера на позицију спецификатора глаголске фразе чији је центар глагол cerca. На позицији спецификатора глаголске фразе глагол јој додељује тематску улогу агенса. Потом се глагол сеrса помера до позиције Spec, Т и провера обележја флексије. У наредној тачки деривације конституент Sofia помера се до положаја Spec, TP. На тој позицији се, будући да је глагол сеrсare у финитном облику, проверава њен падеж номинатива, што је представљено синтаксичким стаблом:

позиција спецификатора временске фразе, без обзира на аргументску структуру глагола, мора бити испуњена, што значи да све реченице морају имати субјекат (Chomsky, 1982). 


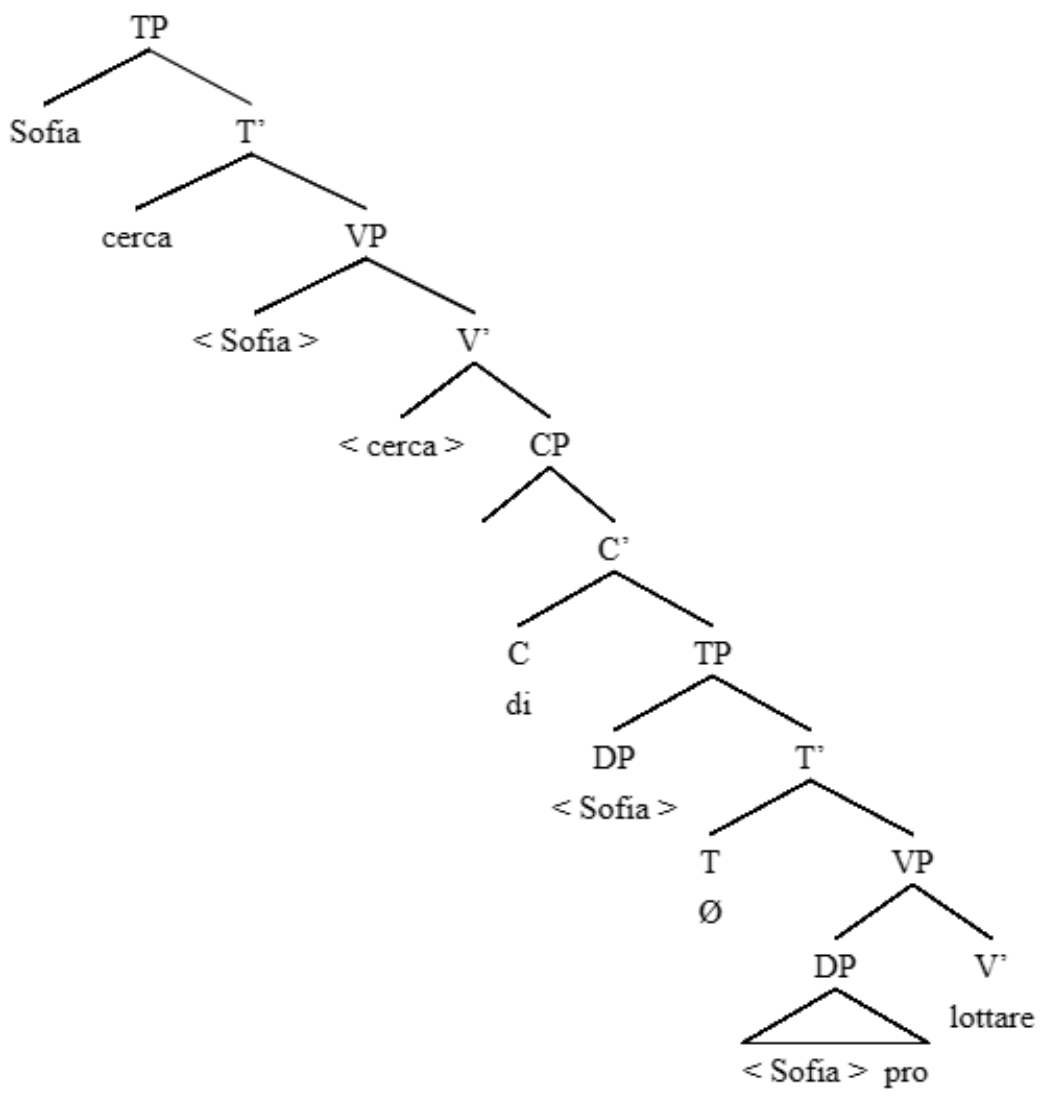

На крају се копије конституента Sofia, које се налазе на нижим позицијама у синтаксичком стаблу, бришу и настаје структура Sofia cerca di lottare. У зависности од вредности фонетски неисказане заменице pro, контролисани елемент семантички може бити у првом лицу множине (када фонетски неисказана заменица има вредност првог лица једнине или множине), другом лицу множине (када је фонетски неисказана заменица у другом лицу једнине или множине или када се подразумева хонорифичка заменичка форма) или трећем лицу множине (када је фонетски неисказана заменица у трећем лицу једнине или множине). Морфолошки, делимични контролор је у једнини, што показује и флексија предиката управне реченице. 


\section{Закључак}

На основу анализе примера присутних у нашем корпусу закључујемо да инфинитивне допунске конструкције са финалним значењем делимичне контроле у италијанском језику могу садржати узајамно-повратне и немаркиране лексички реципрочне глаголе. Имплицитни субјекат зависне клаузе је морфолошки истоветан делимичном контролору, што показује и приказана деривација примера Sofia cerca di lottare. Међутим, у свим испитаним примерима нашега корпуса PRO је семантички у множини. У зависности од морфолошког лица контролора и од вредности фонетски неисказане заменице, имплицитни субјекат семантички може бити у првом, другом или трећем лицу множине, као што је приказано у табели (Табела 1). Будући да је радња која се изражава допунским инфинитивним конструкцијама са финалном значењском компонентом постериорна у односу на радњу управне реченице, у свим анализираним примерима приказана је делимична контрола у зависним реченицама са инфинитивом презента. У нашој грађи није забележен ниједан пример допунске финалне конструкције са финалним значењем са прошлим инфинитивом, те би предмет даљих истраживања могло бити испитивање делимичне субјекатске контроле у узрочним и временским реченицама, које садрже прошли инфинитив.

\begin{tabular}{|c|c|c|c|}
\hline $\begin{array}{c}\text { Морфолошко } \\
\text { лице делимичног } \\
\text { контролора }\end{array}$ & $\begin{array}{c}\text { Семантичко } \\
\text { лице делимичног } \\
\text { контролора }\end{array}$ & $\begin{array}{c}\text { Морфолошко } \\
\text { лице } \\
\text { контролисаног } \\
\text { елемента (PRO) }\end{array}$ & $\begin{array}{c}\text { Семантичко } \\
\text { лице } \\
\text { контролисаног } \\
\text { елемента (PRO) }\end{array}$ \\
\hline прво лице једнине & прво лице једнине & $\begin{array}{c}\text { прво лице } \\
\text { једнине }\end{array}$ & $\begin{array}{l}\text { прво лице } \\
\text { множине }\end{array}$ \\
\hline \multirow{2}{*}{ друго лице једнине } & \multirow{2}{*}{$\begin{array}{c}\text { друго лице } \\
\text { једнине }\end{array}$} & \multirow{2}{*}{$\begin{array}{c}\text { друго лице } \\
\text { једнине }\end{array}$} & $\begin{array}{l}\text { прво лице } \\
\text { множине }\end{array}$ \\
\hline & & & $\begin{array}{c}\text { друго лице } \\
\text { множине }\end{array}$ \\
\hline
\end{tabular}


ДЕЛИМИЧНА СУБЈЕКАТСКА КОНТРОЛА ИНФИНИТИВНИХ ДОПУНСКИХ ...

\begin{tabular}{|c|c|c|c|}
\hline \multirow{3}{*}{ треће лице једнине } & \multirow{3}{*}{$\begin{array}{c}\text { треће лице } \\
\text { једнине }\end{array}$} & \multirow{3}{*}{$\begin{array}{c}\text { треће лице } \\
\text { једнине }\end{array}$} & $\begin{array}{c}\text { прво лице } \\
\text { множине }\end{array}$ \\
\hline & & & $\begin{array}{c}\text { друго лице } \\
\text { множине }\end{array}$ \\
\hline & & & $\begin{array}{c}\text { треће лице } \\
\text { множине }\end{array}$ \\
\hline прво лице множине & $\begin{array}{l}\text { прво лице } \\
\text { множине }\end{array}$ & $\begin{array}{l}\text { прво лице } \\
\text { множине }\end{array}$ & $\begin{array}{l}\text { прво лице } \\
\text { множине }\end{array}$ \\
\hline \multirow{2}{*}{$\begin{array}{c}\text { друго лице } \\
\text { множине }\end{array}$} & \multirow{2}{*}{$\begin{array}{c}\text { друго лице } \\
\text { множине }\end{array}$} & \multirow{2}{*}{$\begin{array}{l}\text { друго лице } \\
\text { множине }\end{array}$} & $\begin{array}{c}\text { прво лице } \\
\text { множине }\end{array}$ \\
\hline & & & $\begin{array}{c}\text { друго лице } \\
\text { множине }\end{array}$ \\
\hline \multirow{3}{*}{$\begin{array}{c}\text { треће лице } \\
\text { множине }\end{array}$} & \multirow{3}{*}{$\begin{array}{l}\text { треће лице } \\
\text { множине }\end{array}$} & \multirow{3}{*}{$\begin{array}{l}\text { треће лице } \\
\text { множине }\end{array}$} & $\begin{array}{c}\text { прво лице } \\
\text { множине }\end{array}$ \\
\hline & & & $\begin{array}{c}\text { друго лице } \\
\text { множине }\end{array}$ \\
\hline & & & $\begin{array}{c}\text { треће лице } \\
\text { множине }\end{array}$ \\
\hline
\end{tabular}

Табела 1. Вредности морфолошког и семантичког лица контролисаног елемента и његовог делимичног контролора у инфинитивним допунским конструкцијама са финалном вредношћу

\section{ЛИТЕРАТУРА}

Authier, J. M., Reed, L. (2018). Embedded Predicate Restrictions on Partial Control. University of Pennsylvania Working Papers in Linguistics, 24, 1, 19-27. [on-line]. Доступно преко: https://repository.upenn.edu/pwpl/ vol24/iss1/ [22.11.2019]

Barrie, M., Pittman, C.M. (2004). Partial control and the movement towards Movement. Toronto Working Papers in Linguistics 22, 75-92. [on-line]. Доступно преко: https://twpl.library.utoronto.ca/index.php/twpl/article/ view/6215 [18.10.2019]

Biagini, F. (2013). L'espressione della finalità in russo. Uno studio contrastivo con l'italiano. Bologna: Bononia University Press. 
Boeckh, C., Hornstein, N. et al. (2010). Control as Movement. Cambridge: Cambridge University Press.

Chomsky, N. (1982). Some Concepts and Consequences of the Theory of Government and Binding. Cambridge: MIT Press.

Cordin, P., Lo Duca, M.G. (2003). Configurazioni argomentali: analisi dei verbi "reciproci" in italiano. Classi di verbi, valenze, e dizionari. Esplorazioni e proposte, 31-52. Padova: Unipress.

Cristofaro, S. (2003). Subordination. Oxford: OUP.

Giandoso, G. (2013). Controllo, Contesto e Conoscenze Condivise: un'analisi su più livelli (необјављена докторска дисертација). Università degli Studi Roma Tre, Roma.

Graffi, G. (2015). Che cos'è la grammatica generativa. Roma: Carocci.

Hornstein, N. (2003). On control. In R. Hendrick (ed.), Minimalist Syntax (pp. 6-81). Oxford: Blackwell.

Kapetangianni, K. (2010). The Minimalist Syntax of Control in Greek (необјављена докторска дисертација). The University of Michigan, Michigan.

Landau, I. (1999). Elements of Control (необјављена докторска дисертација). Tel Aviv University, Tel Aviv.

Landau, I. (2000). Elements of Control. Structure and Meaning in Infinitival Constructions. Berlin: Springer.

Landau, I. (2013). Control in Generative Grammar: A Research Companion. Cambridge: Cambridge University Press.

Lawler, J. (1972). A Problem in Participatory Democracy. Studies in Generative Semantics II. Indiana: Indiana University Linguistics Club, Bloomington.

Lichtenberk, F. (1985). Multiple uses of reciprocal situations. Australian Journal of Linguistics 5, 19-41. [on-line]. Доступно преко: https://www. tandfonline.com/doi/abs/10.1080/07268608508599334 [25.10.2019]

Miličević, M. (2014). Leksička i gramatička recipročnost u srpskom jeziku. Primenjena lingvistika 15, 21-38.

Moretti G.B., Orvieto, G.R. (1980). Grammatica italiana. Perugia: Editrice Benucci.

Moskovljević Popović, J. (2015). Odnosi koreferentnosti u složenoj rečenici sa dopunskom klauzom. Južnoslovenski filolog, LXXI, sv. 3-4, 187-202.

Munn, A. (1993). Topics in the Syntax and Semantics of Coordinate Structures (необјављена докторска дисертација). The University of Maryland, College Park.

Pitteroff, M., Alexiadou, A. et al. (2017). Two Mechanisms to Derive Partal Control-Evidence from German. University of Pennsylvania Working 
Papers in Linguistics, 23, 1, 200-210. [on-line]. Доступно преко: https:// repository.upenn.edu/pwpl/vol23/iss1/23 [27.10.2019]

Popović Pisarri, M. (2018). Glagoli s dopunom u infinitivu u italijanskom $i$ srpskom jeziku (neobjavljena doktorska disertacija). Filološki fakultet, Beograd.

Prandi, M. (1995). Le proposizioni finali in italiano: uno studio di grammatica filosofica. Cuadernos de Filología italiana 2, 19-27. Universidad Complutense, Madrid.

Prandi, M., Gross, G. et al. (2005). La finalità. Strutture concettuali e forme di espressione in italiano. Firenze: Olschki.

Puglielli, A., Frascarelli, M. (2008). L'analisi linguistica. Dai dati alla teoria. Cesena/Roma: Caissa Italia editore.

Radford, A. (1997). Syntax: A Minimalist Introduction. Cambridge: Cambridge University Press.

Reed, L. A. (2014). Strenghtening the PRO Hypothesis. Berlin: De Gruyter Mouton.

Rodrigues, C. (2007). Agreement and flotation in partial and inverse partial control configurations. In W.D. Davies \& S. Dubinsky (ed.), New Horizons in the Analysis of Control and Raising (pp. 213-229). Dordrecht: Springer.

Schmidtke-Bode, K. (2009). A Tipology of Purpose Clauses. Amsterdam: John Benjamin.

Sheehan, M. (2012). Anew take on partial Control: defective thematic intervention. Cambridge Occasional Papers in Linguistics 13, 1-47. [on-line]. Дocтупно преко: http://www.ling.cam.ac.uk/COPIL/papers/6-sheehan.pdf [12.11.2019]

Sheehan, M. (2014). Partial control in Romance languages: the covert comitative analyses. In K. Lahousse, S. Marzo (ed.), Romance Languages and Linguistic Theory 2012: Selected papers from 'Going Romance' Leuven 2012 (pp. 181-198). Amsterdam: John Benjamins.

Sheehan, M. (2018). On the difference between exhaustive and partial control. In F.Cognola \& J. Casalicchio (ed.), Null Subjects in Generative Grammar: A Synchronic and Diachronic Perspective (pp. 141-171). Oxford: Oxford University Press.

Skytte, G. (1983). La sintassi dell'infinito in italiano moderno. Copenaghen: Munksgaards Forlag.

Williams, E. (1980). Predication. Linguistic Inquiry 11, 203-238. Cambridge: The MIT Press. 
Wilkinson, R. (1976). Modes of Predication and Implied Adverbial Complements. Foundations of Language 14, 153-194.

Witkos, J., Snarska, A. (2008). On Partial Control and Parasitic PC Effects. SKASE Journal of Theoretical Linguistics, 5, 1, 42-75. [on-line]. Доступно преко: http://www.skase.sk/Volumes/JTL11/pdf_doc/3.pdf [3.9.2019]

\section{Извори}

CORIS - Corpus dell'italiano scritto. Facoltà di Lettere e Filosofia, Università di Bologna, Bologna. [on-line]. Доступно преко: http://corpora.dslo.unibo. it/TCORIS/

Corriere della sera. Milano: RCS MediaGroup. [21.10.2019]

Il Giorno. Bologna: Monrif Group. [on-line]. Доступно преко: https://www. ilgiorno.it/ [5.8.2019]

Il Mattino. Roma: Caltagirone Editore. [6.9.2019]

Il Venerdi. Roma: GEDI Gruppo Editoriale. [2.8.2019]

La Repubblica. Roma: GEDI Gruppo Editoriale. [15.10.2019]

Jelena D. Puhar

\section{CONTROLLO PARZIALE DEL SOGGETTO NEI COSTRUTTI INFINITIVI COMPLETIVI CON VALORE FINALE IN LINGUA ITALIANA}

\section{Riassunto}

In questo contributo, nell'ambito di grammatica generativa, viene esaminato il controllo parziale del soggetto nei costrutti infinitivi finali retti da verbi in lingua italiana. L'analisi viene condotta su esempi tratti dal corpus Coris nonché su quelli tratti dai media italiani elettronici e cartacei. I risultati della ricerca confermano che i costrutti infinitivi completivi finali di controllo parziale contengono verbi reciproci e che il loro soggetto silente (PRO) semanticamente è sempre al plurale.

Parole chiave: controllo parziale, soggetto silente, costrutti infinitivi completivi finali, lingua italiana, grammatica generativa 